\title{
As implicações da teoria do valor de Marx para a ética: uma interpretação a partir da "obra ontológica" de Lukács
}

\author{
João Leonardo Gomes Medeiros*
}

\begin{abstract}
Resumo
É relativamente bem conhecido o fato de que Lukács dedicou seu último esforço intelectual à elaboração de uma ontologia que estabelecesse o sedimento para a construção de uma Ética marxista. Seguindo as indicações deixadas por Lukács em sua Ontologia do Ser Social, sobretudo no capítulo dedicado à categoria do trabalho, torna-se possível delinear o que parecem ser os fundamentos ontológicos de uma Ética inspirada na teoria social marxiana. $\mathrm{O}$ artigo procura sustentar que Lukács pretendia defender o caráter objetivo das categorias centrais da Ética (o valor, o dever-ser e os juízos de valor) mediante a demonstração das conexões existente entre essas categorias, a prática humana e as estruturas sociais que as condicionam. Esse legado da "obra ontológica" de Lukács é aproveitado como base teórica de uma proposta de reinterpretação da teoria do valor de Marx, reinterpretação essa que explicite as implicações de sua crítica social para o campo da ética.
\end{abstract}

Palavras-Chave: teoria do valor, Marx, Lukács, ontologia, ética, prática humana.

\section{Introdução}

E $\mathrm{m}$ um de seus mais recentes trabalhos, o crítico literário irlanZdês Terry Eagleton abordou, em sua prosa elegante, além de teoricamente embasada, a intrincada relação de Marx com as questões ético-morais:

\footnotetext{
Professor Adjunto do Departamento de Economia da Universidade Federal Fluminense,
} Niterói/RJ. Endereço eletrônico: jlgmedeiros@vm.uff.br. 


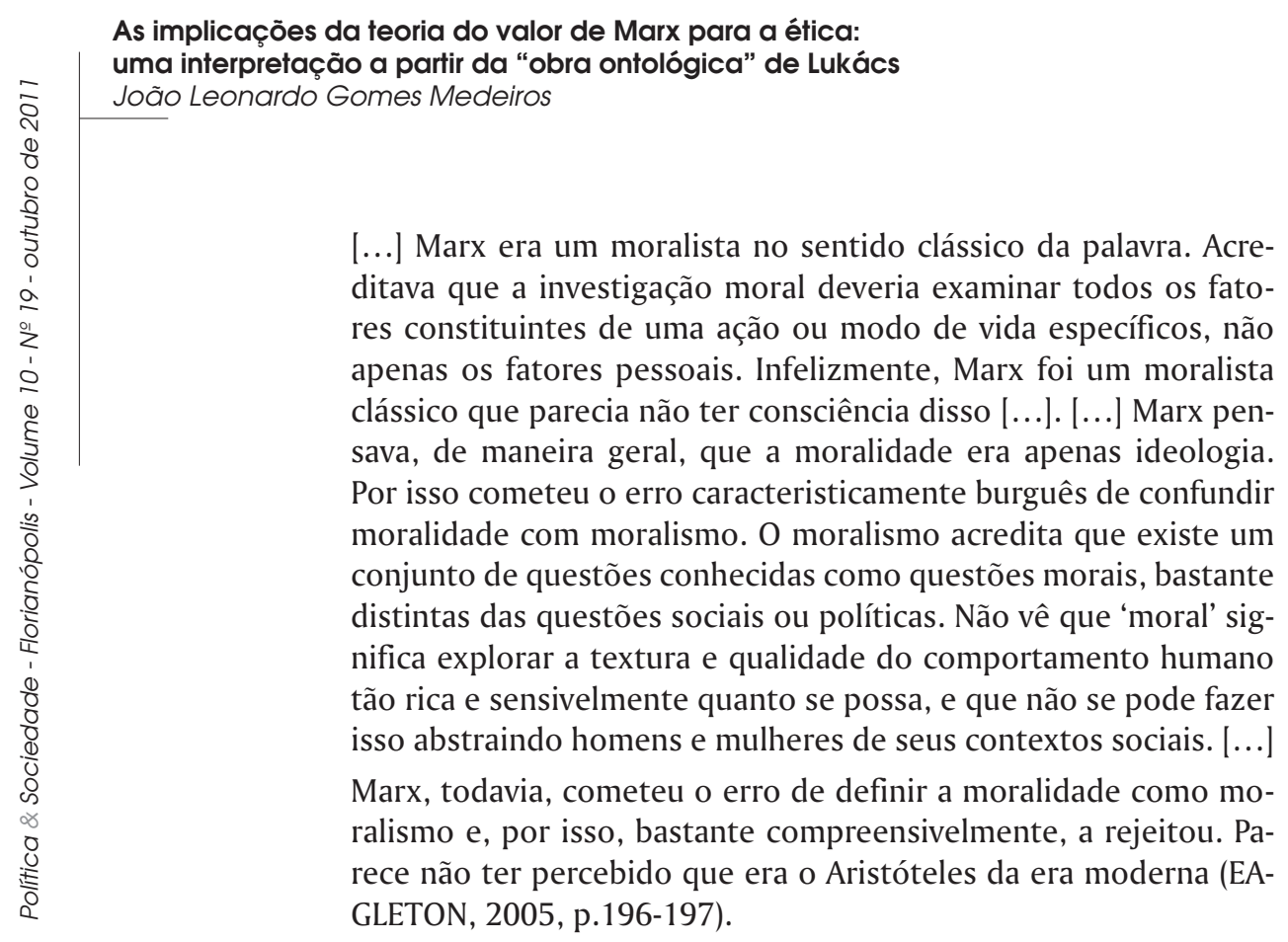

Opiniões como essa, emitida por um marxista de primeiríssima linha, reforçam a percepção, muito difundida, de que a ética é um tema dos mais polêmicos dentre aqueles que estão associados à elaboração de uma teoria social marxista. ${ }^{1}$ Muitos julgam a construção de uma ética materialista um projeto absolutamente inconciliável não apenas com as formulações originais de Marx, mas com a teoria social em geral. Não são poucos também os que consideram, no sentido exatamente oposto, que conciliar a teoria social de Marx com uma concepção ética consistente é não apenas necessário, mas, de fato, urgente. São relativamente escassas, no entanto, as tentativas de estabelecer teoricamente a conexão entre os elementos centrais da teoria e da crítica social de Marx com o campo da ética.

Dentre os pensadores cuja obra pode ser considerada inequivocamente um capítulo dos clássicos do marxismo, o autor que manifestou de modo mais regular e consistente o desejo de estabelecer a conexão entre os dois campos, a teoria social de Marx e

1 A respeito da polêmica em torno da possibilidade de conciliar preocupações com a temática da ética e a concepção geral de Marx a respeito da sociedade, ver Brenkert (1983, Capítulo 1); Kain (1991) e Eagleton (2005). 
a ética, foi Lukács. ${ }^{2}$ É bastante conhecido, contudo, o fato de que Lukács considerava que a sua ética marxista só poderia ser elaborada sobre a base de uma ontologia do ser social que explicitasse os fundamentos filosóficos (ontológicos) das concepções de Marx, de modo a sustentar solidamente o desenvolvimento da tradição marxista. ${ }^{3}$

Este artigo sugere uma interpretação da teoria do valor de Marx, cujos fundamentos são apresentados logo nos primeiros capítulos de 0 Capital (Marx, 1998), inspirada teoricamente nas indicações dispersas, mas muito instigantes, deixadas por Lukács no trabalho que ocupou os seus últimos anos de vida, a Ontologia do Ser Social, ${ }^{4}$. Do extenso argumento da Ontologia de Lukács, o interesse recai sobre um momento de sua análise da prática humana, no qual o autor revela uma conexão decisiva entre dois campos da vida social não raramente apartados nas teorias éticas: o valor (e, a partir dele, o dever-ser) e a práxis. É com base no fundamento teórico oferecido neste argumento específico de Lukács, portanto, que se pretende retomar a teoria do valor de Marx para pôr em destaque algumas de suas implicações que parecem plenas de conteúdo quando tomadas como afirmações no campo da ética.

$\mathrm{O}$ argumento do artigo é desenvolvido em quatro seções. Na seção a seguir, procura-se recompor o nexo entre ética e ontologia da forma como acreditamos que Lukács o tenha concebido. A seção

2 Cf.: Lukács (2007b; 1979) ou o comentário de Tertulian (2007).

3 Como disse Tertulian, "Não se deve esquecer que a Ontologia do Ser Social nasceu a partir de um vasto campo de pesquisas. Após vários anos de investigações consagrados aos problemas da ética, [...], ele se deu conta de que a especificidade da atividade ética não pode ser estabelecida sem uma reflexão de conjunto, de caráter polifônico, sobre os principais componentes da vida social (economia, política, direito, religião, arte, filosofia): a Ontologia do Ser Social representa a concretização deste vasto programa totalizante, destinado a preparar a Ética que, infelizmente, não foi escrita". (TERTULIAN, 2007, p.227-228)

4 Não há (ainda) uma tradução integral da Ontologia do Ser Social para o português. Neste artigo, serão utilizadas a tradução já publicada do capítulo sobre Marx - Lukács (1979) -, e a tradução, ainda não publicada, do capítulo sobre o trabalho elaborada por Ivo Tonet e reformulada por Mario Duayer, que circula como manuscrito entre os que se ocupam da obra. Para formalizar as indicações e citações de passagens deste capítulo sobre o trabalho, adotou-se como referência a tradução para o espanhol (LUKÁCS, 2004). 


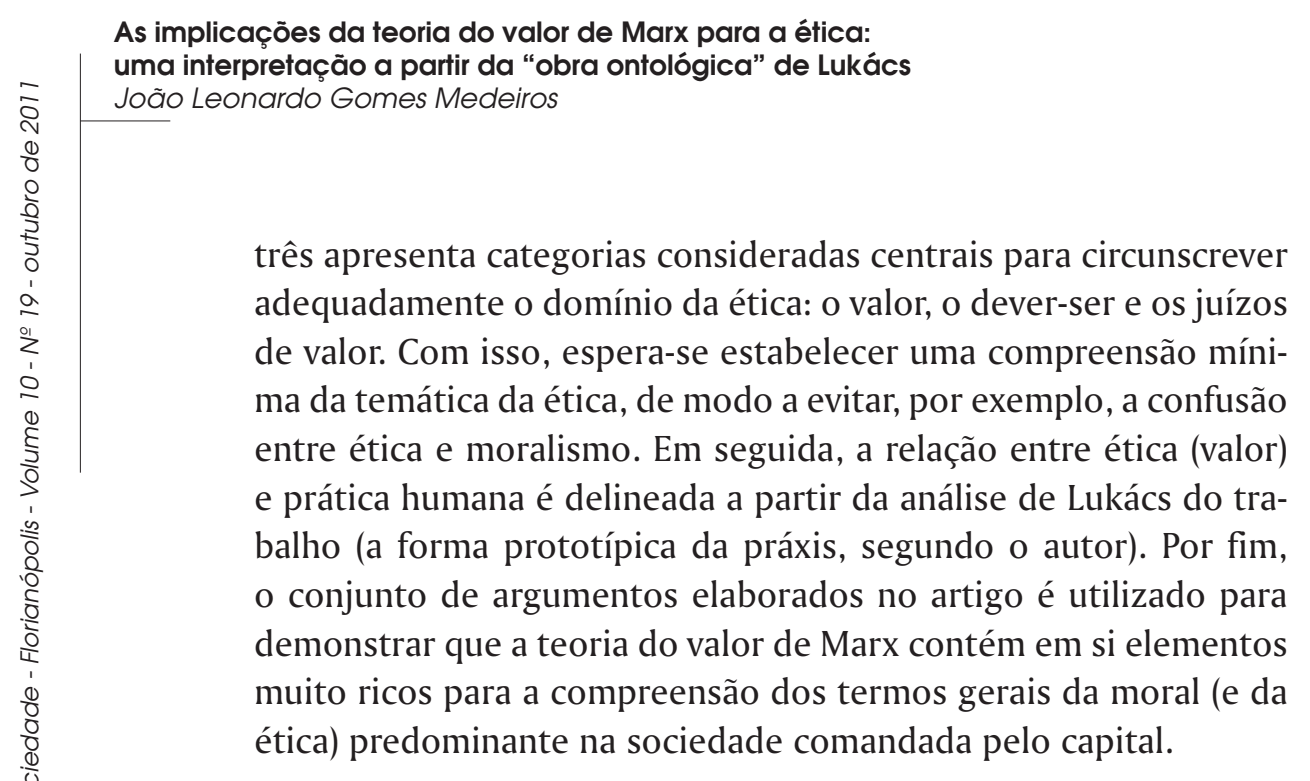

\section{Lukács e a defesa da crítica ontológica: o nexo entre ontologia e ética}

Antes de empregar os desenvolvimentos da Ontologia de Lukács para abordar a relação entre ética, ontologia e a teoria social de Marx, é preciso esclarecer o significado da "virada ontológica" que tornou aquele primeiro autor efetivamente consciente da necessidade de elaborar uma teoria sobre a ética e de fundamentá-la ontologicamente. O ponto de partida para compreender essa questão encontra-se, como não poderia deixar de ser, na própria categoria da ontologia.

Numa apresentação sucinta, muito genérica, a ontologia pode ser descrita como o conjunto de considerações gerais sobre a realidade, sobre o ser, sobre o que existe efetivamente em si, uma visão geral de mundo enfim, que constitui o pano de fundo para a interpretação dos diferentes momentos da existência natural e/ou social. ${ }^{5}$ A decisão de Lukács de dotar seu trabalho de uma sólida base ontológica e, posteriormente, o projeto de explicitar a ontologia subjacente às concepções de Marx devem-

5 O termo "ontologia" também pode ser empregado para se referir tanto ao que existe em si mesmo quanto às considerações sobre o existente. Trata-se aqui de uma duplicidade léxica semelhante à que ocorre com economia ou história, que podem se referir à ciência econômica e da história ou às relações econômicas e à história propriamente. 
-se ao reconhecimento de que, inescapavelmente, toda produção intelectual traz consigo subtendida uma imagem geral de mundo (uma ontologia), que necessariamente difunde. Isto é, que todas as concepções particulares pressupõem e veiculam uma interpretação do mundo que se opõe criticamente a outras interpretações.

Isso vale, é claro, mesmo para aquelas concepções idealistas que nos asseguram que nós não temos como acessar o mundo intelectualmente, ou que o conhecimento é, no final das contas, impossível. Não é difícil perceber que, por detrás dessa consideração sobre a (im)possibilidade do conhecimento - admitida, de modos distintos, por autores como Popper, Kuhn, Lakatos, pelos instrumentalistas em geral, pelos pós-modernos, pragmáticos, entre muitos outros - está uma afirmação ontológica nem sempre explicitada e raramente justificada: a de que o mundo é de uma forma tal que não pode ser reproduzido corretamente no pensamento. Com o arsenal crítico de que se dispõe hoje, pode-se demonstrar sem muito esforço que a ontologia (a visão de mundo) pressuposta por todas essas concepções implícita ou explicitamente idealistas baseia-se na categoria da experiência, aproximando-se, portanto, da ontologia pressuposta na tradição positivista, que constitui exatamente o objeto imediato de crítica do "novo" idealismo. ${ }^{6}$

Explorar aqui essa aparentemente curiosa, mas de forma alguma surpreendente, unidade ontológica entre posições que são tidas como antitéticas afastaria, contudo, o argumento de sua linha central, de maneira que nos limitaremos à indicação acima.

6 Cf.: O filósofo inglês Roy Bhaskar (1997, p.28) não apenas enfatiza a "convergência ontológica" entre o positivismo e os seus críticos relativistas, como se vale do reconhecimento dessa convergência para dirigir às duas tradições uma crítica comum. A passagem a seguir apresenta, em linhas gerais, a maneira como o autor expressa a mencionada "convergência ontológica": "Nem o empirismo clássico [i.e., a tradição positivista] nem o idealismo transcendental [i.e., a filosofia anti-realista, relativista] podem sustentar a idéia da existência e ação independente das estruturas causais e das coisas investigadas e descobertas pela ciência. É na ontologia que compartilham que reside essa incapacidade comum. Pois o idealismo transcendental, embora rejeite a explicação empirista de ciência, assume tacitamente a explicação empirista do ser. Esse legado ontológico é expresso mais sucintamente em seu compromisso com o realismo empírico e, em conseqüência, com o conceito de "mundo empírico". Cf.: também Bhaskar (1998); Duayer, Medeiros \& Painceira (2000). 


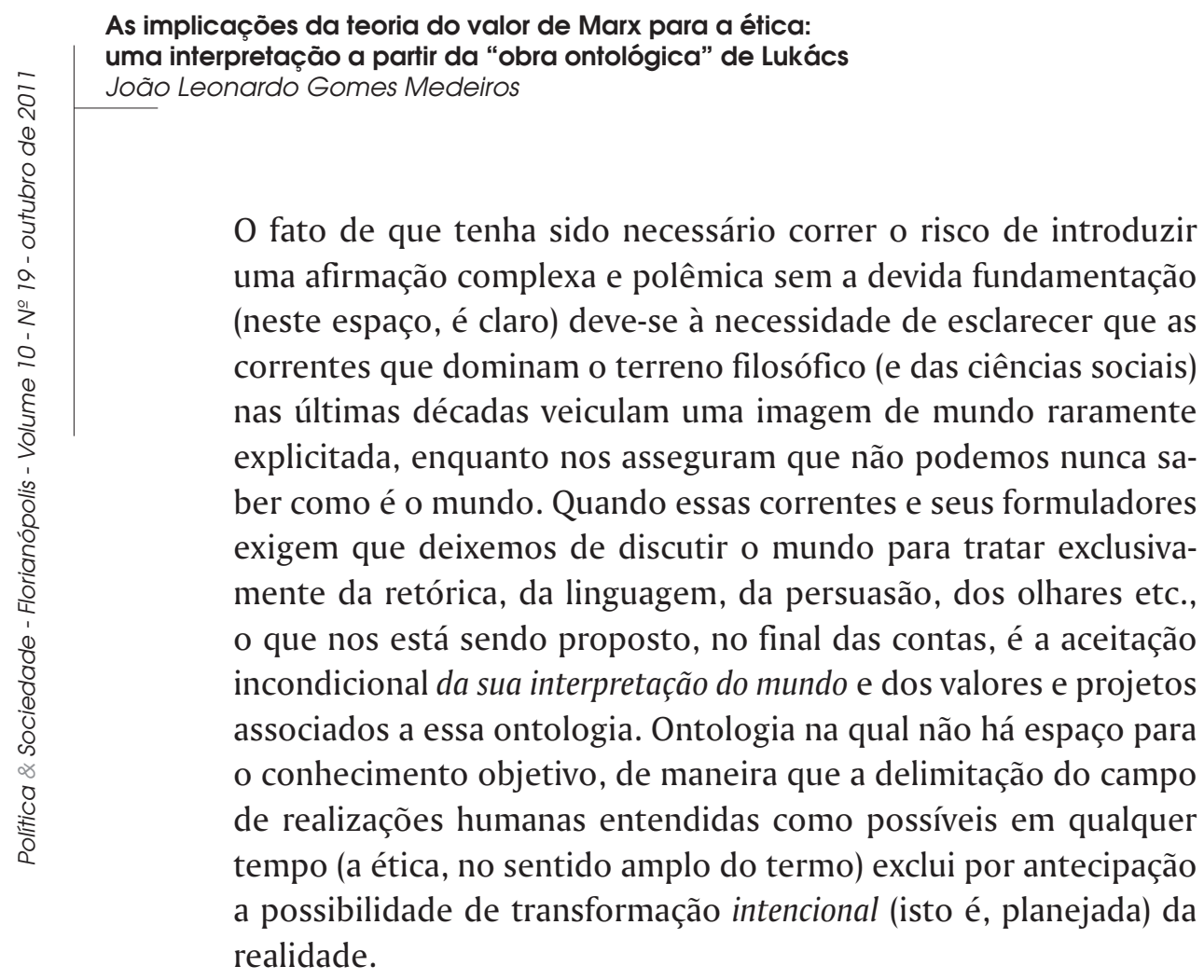

A "virada ontológica" de Lukács é o exato oposto dessa atitude que muitos denominaram "virada linguística". Pois o que Lukács defende abertamente em sua obra madura é a necessidade de explicitar as visões de mundo e as imagens de futuro concebidas e projetadas pelas diversas teorias filosóficas e científicas (isto é, sua ontologia e sua ética), permitindo um contraste igualmente aberto entre as interpretações do passado e do presente e as figurações do futuro. ${ }^{7}$ Uma vez que isso tenha sido feito, é finalmente possível discutir não apenas a questão de que projeto é desejável, mas também de que projeto é efetiva e concretamente exequível.

7 Ao final da Segunda Grande Guerra, Lukács explicitou esse ponto de vista a respeito da escolha entre os projetos de sociedade: "Não é por acaso [...] que [os problemas éticos] são centrais na crise ideológica de nossa época. De fato, raramente a humanidade se encontrou de modo tão consciente - como hoje se encontra - diante da decisão a tomar sobre o seu próprio destino. Seja em face da complexa conjuntura histórico-mundial [...], seja em face de todo ato de sua vida individual, os homens estão sempre diante de uma escolha. Ontem, tratava-se de decidir a favor ou contra o fascismo; e hoje, colocado perante cada mudança política cotidiana, o homem se vê frente a escolhas carregadas de consequências (LUKÁCS, 2007b, p.71). 
Naturalmente, o cotejamento entre ontologias que Lukács exercita em sua obra (refiro-me à Ontologia do Ser Social) subentende o juízo de que, uma vez reveladas as imagens de mundo contidas em cada forma de consciência particular (na religião, na arte, na filosofia, nas diferentes teorias científicas, na ontologia espontaneamente formada na prática social de uma época), essas imagens de mundo podem ser diretamente comparadas como projetos para a sociedade. Ou seja, elas podem ser avaliadas e contrastadas como valores (propósitos, finalidades, objetivos, anseios, desejos, necessidades sociais) que os seres humanos procuram realizar em sua prática. Nesse contraste, é claro, recusa-se (ajuíza-se negativamente) determinadas ontologias e a suas éticas correspondentes e afirma-se outra (ajuizada de modo positivo).

Não é um exagero afirmar que o Lukács maduro apostou todas as suas fichas no projeto de explicitar a ontologia do ser social de Marx (e a ética que se desdobrava a partir dela), para que essa ontologia servisse de ponto de apoio ao escrutínio crítico das propostas ético-ontológicas concorrentes. Esse trabalho seria favorecido pelo fato de que todas as concepções marxianas e, em particular, todas as categorias a partir das quais essas concepções interpretam e representam o mundo são "formas do ser, determinações da existência" - para citar uma passagem de Marx que Lukács repete insistentemente (MARX, 1974, p.127). Com a frequente referência a essa passagem, Lukács procura salientar que todas as categorias descobertas por Marx referem-se a objetos e determinações concretamente existentes, mesmo naqueles casos em que as categorias dão conta de âmbitos da realidade nos quais a forma aparente do objeto (a sua existência como categoria, portanto) revela o exato oposto de sua essência, de maneira que a categoria demonstra-se objetivamente "falsa" (mistificadora) - isto é, falsa, mas socialmente necessária. ${ }^{8}$

8 O capítulo sobre Marx da Ontologia inicia exatamente com essa questão: o reconhecimento da fluência social e, portanto, do caráter ontológico e necessário das falsas idéias. De acordo com Lukács (1979, p.14), Marx põe em primeiro plano "a função prático-social de determinadas formas de consciência, independente do fato de que elas, no plano ontológico geral, sejam falsas ou verdadeiras". Sobre o caráter ontológico das colocações marxianas, ver também Duayer (2001) ou Lukács (2007a, p.225-227). 


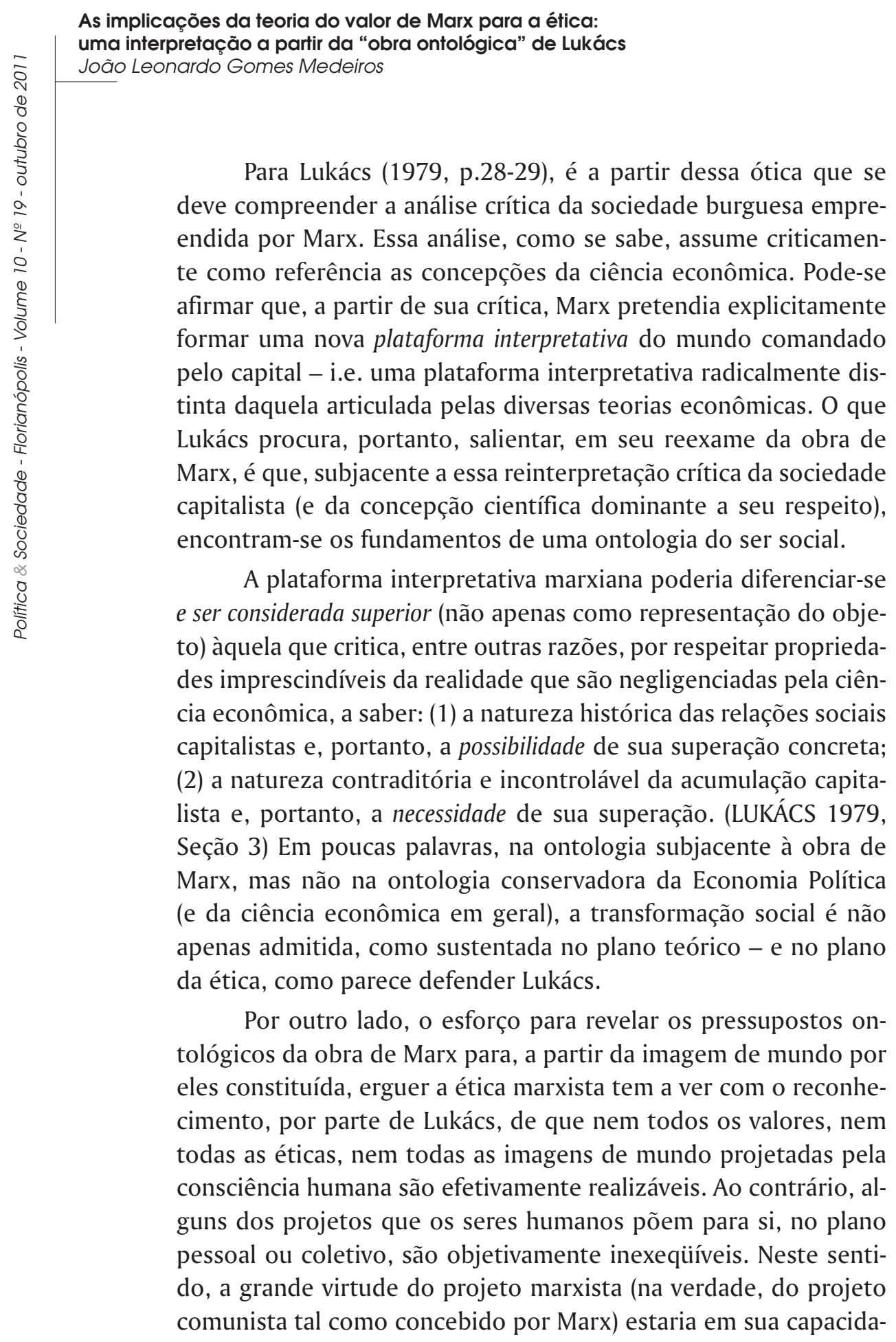


de de revelar aos seres humanos um futuro no qual seria possível realizar concretamente o projeto da emancipação do gênero - algo inacessível a todos os projetos conservadores com os quais o marxismo rivalizava e ainda rivaliza (LUKÁCS, 2007b, p.240-244).

Conferir ao marxismo os fundamentos filosóficos (ontológicos) necessários para enfrentar as concepções burguesas no plano teórico e também no da prática social parece ser, como dito, a grande motivação da obra madura de Lukács. Nas seções que se seguem, recolhemos algumas das pistas deixadas pelo autor nesse trabalho para formar, a partir daí, a base da reinterpretação da teoria do valor de Marx que este artigo propõe.

\section{A ética e as suas categorias fundamentais: o valor, o dever-ser e os juízos de valor}

Um ponto de partida frutífero para compreender a forma como, aparentemente, Lukács pretendia explicitar o conteúdo ético da teoria social de Marx é estabelecer os termos da contradição entre a ética idealista, tipicamente elaborada no âmbito da filosofia burguesa, e o marxismo (na verdade, a ontologia marxiana). ${ }^{9}$ Essa contradição relaciona-se diretamente com o fato de que, numa concepção idealista da ética, os valores são simplesmente postulados, sem que as condições objetivas de sua realização sejam levadas em consideração. Na passagem abaixo, Lukács identifica algumas das insuficiências e contradições dessa posição filosófica que se relacionam direta ou indiretamente ao problema da realização dos valores, que enfatizaremos no argumento a seguir: ${ }^{10}$

9 No caso da ética idealista, a referência de Lukács (2007a, p.72) é a formulação de Kant, mas podemos encontrar um exemplo mais recente na conhecida teoria da justiça de Rawls (1997), na qual o autor, inspirado em Kant, profere valores em abstrato (sob a forma de "bens primários"). É interessante perceber que Lukács rompeu conscientemente com a influência da ética kantiana em sua obra da juventude. Cf.: Lukács (2003, p.4).

10 É preciso assinalar que a preocupação central da crítica de Lukács às concepções idealistas da ética é o hiato por elas estabelecido entre a vida social concreta e a moral e não exatamente o problema da realização dos valores. Para o argumento deste artigo, entretanto, à ênfase recai sobre a questão da realização, porque o objetivo é enfatizar o fato de que a reprodução do capital (i.e., do trabalho estranhado) não apenas condiciona, como muitas vezes impede a realização de determinados propósitos humanos. 


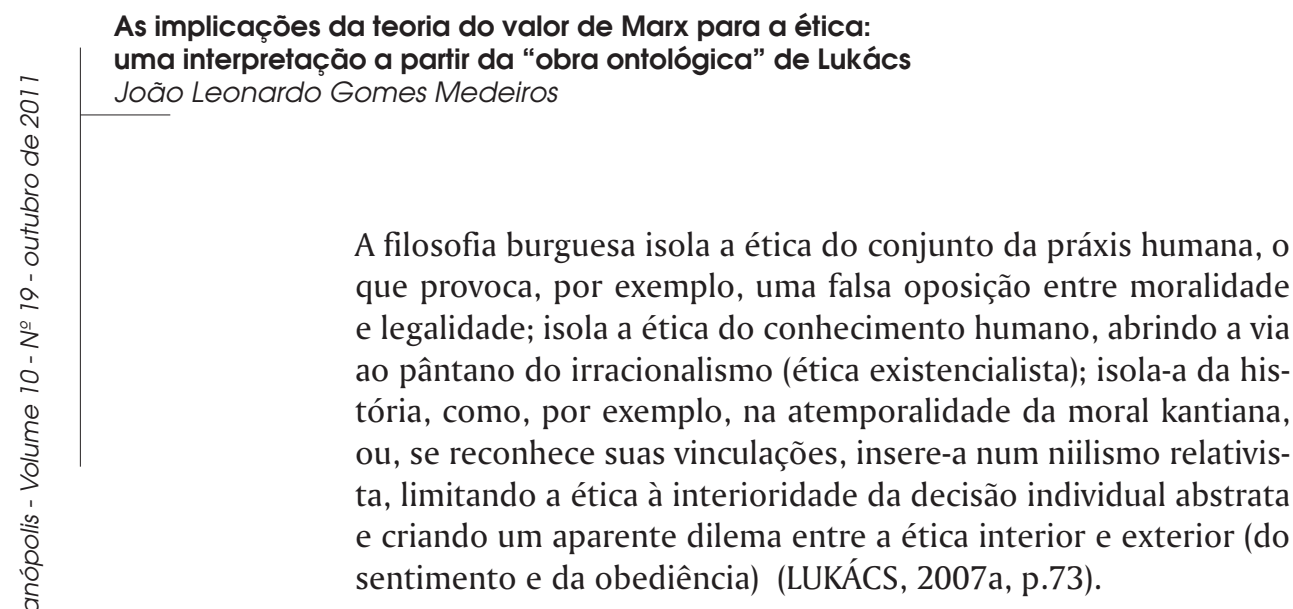

A crítica da ética idealista (burguesa) exige um tratamento rigoroso não apenas da questão da ética, mas também de sua relação com a ontologia, a moral e os juízos de valor. E a primeira coisa que se deve considerar ao empregar categorias às quais são atribuídas significados tão diversos, como é o caso da ética e da moral, é o seu efetivo significado ontológico: ou seja, que tipo de objetos concretamente existentes são (ou deveriam ser) reunidos sob estas designações e refletidos nos campos da filosofia nos quais são tratados. Para delimitar o terreno da análise, é preciso ter clareza a respeito do conteúdo das categorias cruciais desse campo da filosofia, que são nitidamente o valor, o dever-ser e os juízos de valor.

Para tratar com rigor dessas três categorias fundamentais, é preciso antes demarcar o próprio campo da ética, o que faremos aqui tomando por base uma interpretação livre das formulações apresentadas por Lukács em textos diversos. Para o autor, por exemplo em (2007a, p.72), "a ética é uma parte, um momento da práxis humana em seu conjunto" ou, para ser mais específico, o momento da práxis humana em que os seres humanos formam um juízo sobre a própria conduta. Em sua análise da práxis humana, que sintetizamos na seção seguinte, o autor pretende demonstrar que as categorias a partir das quais os seres humanos formam juízos sobre sua própria prática - precisamente o valor e o dever-ser, além dos próprios juízos de valor - comparecem como momentos indispensáveis já na forma de prática humana ontologicamente originária - o trabalho.

Por ora, o importante é perceber a conexão da ética com a categoria decisiva neste domínio da prática humana, a saber, o 
valor. Não é difícil, na verdade, defender a relevância ontológica do valor na ética. Isso porque todas as avaliações da prática humana têm por base o conjunto de finalidades (objetivos, propósitos, carecimentos) que orientam e dão sentido às ações humanas, sendo essas finalidades exatamente aquilo que se denomina, numa concepção abrangente, valores. ${ }^{11}$ Em termos mais simples, uma ação pode ser dita boa/ruim eficiente/fracassada, útil/inútil etc. conforme o tipo de finalidade (valor) que ela pretende objetivar. ${ }^{12}$ Por isso se pode reconhecer os valores como a categoria básica da ética e a própria ética (entendida agora como campo de conhecimento filosófico) ${ }^{13}$ como o estudo da origem dos valores, de seu desenvolvimento, de seu estatuto ontológico, da relação dos diferentes sistemas de valores e de sua conexão com as práticas humanas e com o próprio desenvolvimento social.

Por exemplo, pode-se falar de uma ética religiosa, que, para citar o caso da tradição cristã, é delimitada pelo conjunto de valores cuja realização presumidamente conciliaria a vida humana com a suposta teleologia concebida por deus para o universo. Esse caso da ética religiosa é muito adequado para estabelecer de forma clara a conexão entre a ética (o momento avaliatório da prática humana) e a moral (o comportamento formado pelas avaliações éticas). Para isso, basta ter em conta que - esticando o exemplo - ao conjunto de valores que, uma vez realizado, seria capaz de objetivar o projeto de deus para humanidade, corresponde um padrão de comportamento determinado.

11 É preciso advertir que reconhecer a relação entre valor e finalidade da práxis não implica aceitar a identificação entre valores e objetivos da prática imediata, típica do pragmatismo. Quanto ao pragmatismo, pode-se sugerir que a associação entre valor e objetivo imediato é consistente com a sua tese central de que a prática humana é circunscrita pelas possibilidades imediatamente dadas. Uma vez que se rejeite essa noção restritiva da práxis, não há, entretanto, razão para aceitar a noção igualmente restritiva dos valores como finalidades imediatas.

12 Não é difícil encontrar a procedência dessa concepção da ética que associa o valor (bem) às finalidades: Aristóteles. Já nas primeiras páginas de sua Ética a Nicômaco, o autor afirma: "Considera-se que toda arte, toda investigação e igualmente todo empreendimento e projeto previamente deliberado colimam [visam] algum bem, pelo que se tem dito, com razão, ser o bem a finalidade de todas as coisas" (ARISTÓTELES, 2007, p.37).

13 A ética e a moral também são categorias marcadas pela duplicidade léxica a que fizemos referência na nota 6 acima. 


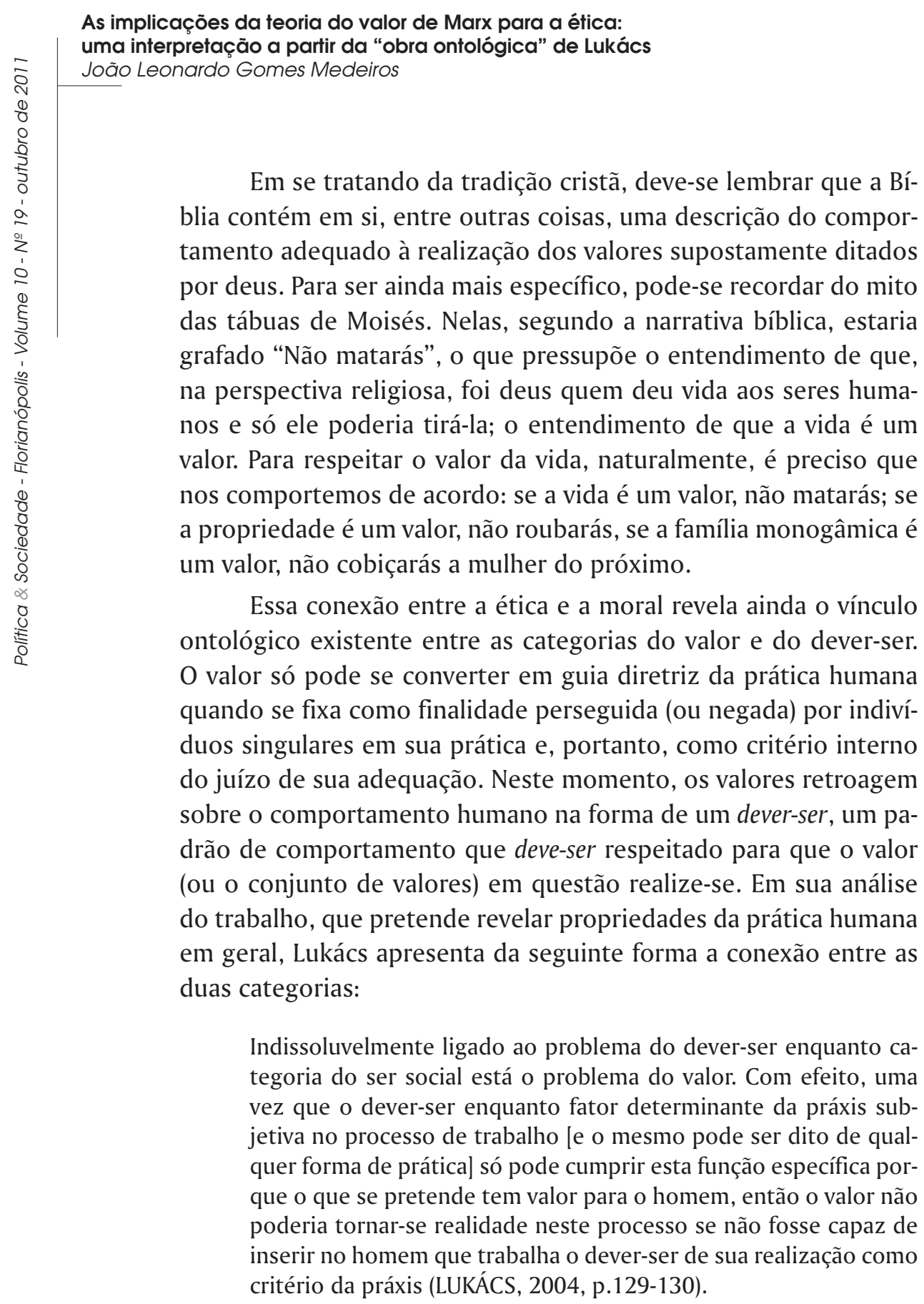


Embora se refiram a momentos distintos da práxis (a finalidade, no caso do valor, e a conduta que o realiza, no caso do dever-ser), as duas categorias "estão unidas de uma maneira tão íntima porque ambas são momentos de um único e mesmo complexo". (Ibid) Na relação entre as duas categorias, como dito acima, é nítido que o dever-ser é determinado pelo valor afirmado na própria práxis. Para cada conjunto de valores, portanto, segue um conjunto de deveres-ser compatível com sua realização. Para variar os exemplos, se se trata de conseguir um emprego, se essa é uma finalidade legítima, um valor, então há um padrão de comportamento, um dever-ser, indispensável para a realização; se se trata de enfrentar a concorrência, deve-se adotar práticas em conformidade; se se trata de chocar a sociedade com uma obra de arte, deve-se produzir a arte com essa capacidade.

Pode-se perceber, ademais, que a retroação dos valores sob a forma de dever-ser constitui a base daquilo que nós usualmente denominamos juízos de valor: se um valor impõe um dever-ser que não é respeitado na prática de um determinado sujeito, podemos considerar sua prática como ruim, inútil, ineficiente, má etc., precisamente porque incompatível com a realização do valor. Por outro lado, a prática compatível com a realização do valor que a motiva pode ser dita acertada, útil, eficiente, boa etc (LUKÁCS, 1979, p.83; 2004, p.135-136).

Admitindo essa formulação para o valor, o dever-ser e para os juízos de valor, pode-se aceitar igualmente que a primeiríssima questão da ética e da moral é a questão da procedência dos valores e, por seu intermédio, do dever-ser e dos juízos de valor - de sua origem objetiva. É possível, neste particular, sugerir uma taxonomia para diferenciar as correntes da ética (e da moral) pela forma como respondem a essa questão. Nesta taxonomia, as diferentes concepções a respeito da procedência dos valores poderiam ser reunidas em dois grandes grupos, descritos a seguir.

O primeiro grande grupo é o da ética idealista. Na concepção idealista da ética - parafraseando a máxima anti-realista de James (1907, p.30) - os valores são considerados aquilo que nós pro- 


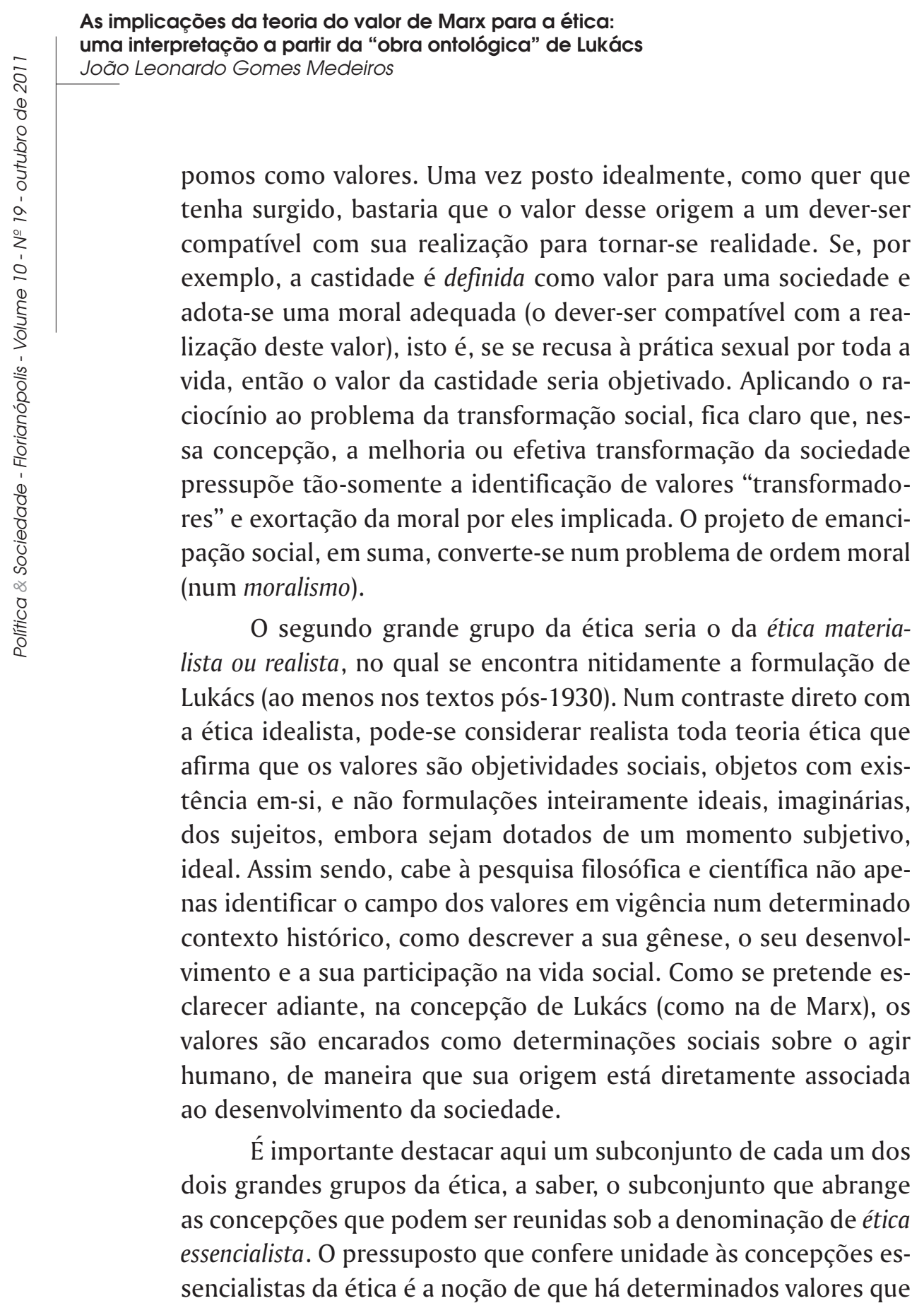


formam uma essência imutável do gênero humano, ${ }^{14}$ isto é, que há um conjunto de valores diretamente implicados por propriedades transcendentes da natureza humana. A identificação dos valores, nesta ótica, teria como ponto de partida o reconhecimento das propriedades da natureza humana.

É preciso aqui alertar para o fato de que, a rigor, essa concepção da ética pode ser associada a uma concepção idealista ou realista não exatamente dos valores, mas da natureza humana. Os essencialistas-idealistas em geral oferecem uma imagem abstrata, elaborada de maneira ad hoc, da natureza do ser humano, à qual corresponderiam determinados valores, padrões de comportamento e juízos de valor. Para os essencialistas-realistas, por outro lado, o estudo da ética deveria começar, em última análise, pela antropologia. A antropologia revelaria os atributos da natureza humana, nas diferentes situações histórico-concretas, e, ao assim fazê-lo, reconheceria os valores correspondentes. ${ }^{15}$

Quem conhece minimamente a autocrítica que Lukács produziu de sua obra da juventude sabe que o autor transitou conscientemente desde uma perspectiva que aqui denominamos idealista (ou, na melhor das hipóteses, desde uma perspectiva essencialista-idealista) da ética até uma perspectiva materialista ou realista. Para isso, bastou que Lukács reconhecesse que os valores, em lugar de serem pura subjetividade humana ou pura objetividade social, são as "formas do ser, determinações da existência" que só adquirem uma forma concreta de manifestação no campo da

14 O subgrupo essencialista exclui as teorias (como a do próprio Lukács, de Marx ou de Eagleton, para ficar entre os autores citados neste trabalho) que admitem que a essência pode ser histórica, e não fixa, congelada no tempo e no espaço. O essencialismo aqui fica associado, portanto, exclusivamente à concepção anistórica de essência.

15 Não faltam exemplos de teorias éticas essencialistas, tanto no campo idealista, como no campo realista. No primeiro caso, pode-se recordar da formulação de Smith, para quem a propensão à troca imanente à natureza humana determinaria a perseguição do comércio como valor. (SMITH, 1985, p.73pp.) Um exemplo notável de essencialismo realista pode ser encontrado em Bhaskar. O autor chega a expressar abertamente esse entendimento do problema dos valores na seguinte passagem: "Assim como a ontologia está para a epistemologia, a antropologia está para a ética; de fato, pode-se afirmar que a antropologia é precisamente a ontologia da ética”. Bhaskar (2009, p.140) 


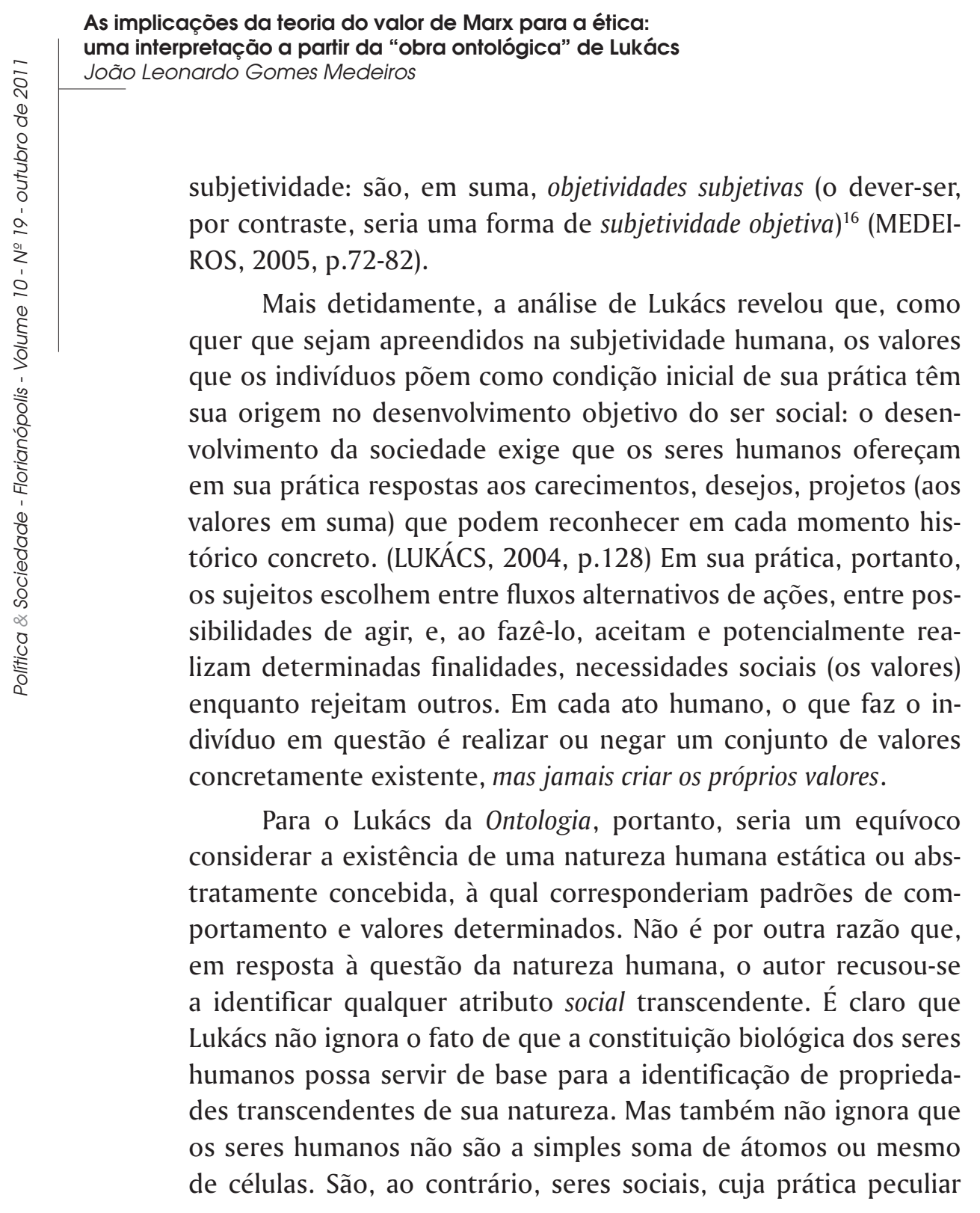

16 Cf.: Lukács (2004, p.130-131). A respeito do caráter simultaneamente objetivo e subjetivo do valor, ver também Vázquez (2007, p.136-150). Outro autor que formula o problema da objetividade particular dos valores de modo semelhante é Lessa (2002, p.127), até porque também parte de Lukács. Acreditamos, no entanto, que a compreensão de Lessa do trabalho como uma categoria hierarquicamente superior no complexo da prática humana distancia a sua posição da do próprio Lukács, para quem a prioridade ontológica do trabalho na vida social não implica qualquer superioridade hierárquica do trabalho com relação às demais formas de práxis humana. 
envolve a modificação da constituição subjetiva e mesmo objetiva (habilidade motora, capacidade de resistência etc.) de sua existência. Por isso, pôde concluir que, do ponto de vista social, o que efetivamente distingue a natureza humana enquanto é a sua notável labilidade: a capacidade de modificar sua própria constituição na e pela práxis. É isso que o autor quis dizer quando caracteriza o ser humano como o "ser que dá respostas" (LUKÁCS, 2007b, p.229) ou como o "ser autofundado" - cuja natureza muda com o próprio desenvolvimento ${ }^{17}$ (LUKÁCS, 2004, p.153).

\section{A ética como momento da prática humana}

Voltemo-nos agora para a forma como Lukács defende o caráter ontológico dos valores e, ao fazê-lo, pavimenta o caminho para a construção de uma ética realista. Considerando os propósitos do presente artigo, a retomada da extensa Ontologia de Lukács tem o propósito de trazer ao primeiro plano "apenas" um argumento: aquele em que o qual o autor demonstra que os valores são momentos inelimináveis das práticas humanas. ${ }^{18}$ (LUKÁCS, 1979, p.167pp.) Para isso, Lukács inspeciona detidamente a forma de prática humana originária, que sedimenta (como "modelo" ontológico) todas as modalidades do agir humano: o trabalho. ${ }^{19}$

Seguindo a conhecida descrição (aristotélico-hegeliana-marxiana) do trabalho, Lukács observa que o trabalho distingue-se como forma de prática tipicamente humana por constituir-se como objetivação de uma finalidade previamente definida, i.e. como materialização de uma idéia. (Lukács, 2004, p.60) Numa

17 Essa parece ser também a perspectiva de Eagleton. Ao mesmo tempo em que ressalta que a nossa constituição humana pressupõe propriedades herdadas da evolução biológica (linguagem, trabalho etc.), o autor reforça o caráter dinâmico de nossa "essência". (EAGLETON, 2005, p.165-167)

18 Uma boa síntese deste ponto pode ser encontrada em (DUAYER; MEDEIROS, 2007).

19 A descrição de Lukács da práxis humana a partir do trabalho é muitíssimo semelhante ao modelo transformacional do agir humano proposto por Bhaskar em (1998, p.33-37). Em ambos os casos, a análise pretende revelar propriedades da prática humana em geral a partir do trabalho e não sustentar a superioridade do trabalho como forma de práxis. Cf.: Lukács (2004, p.103-104). 


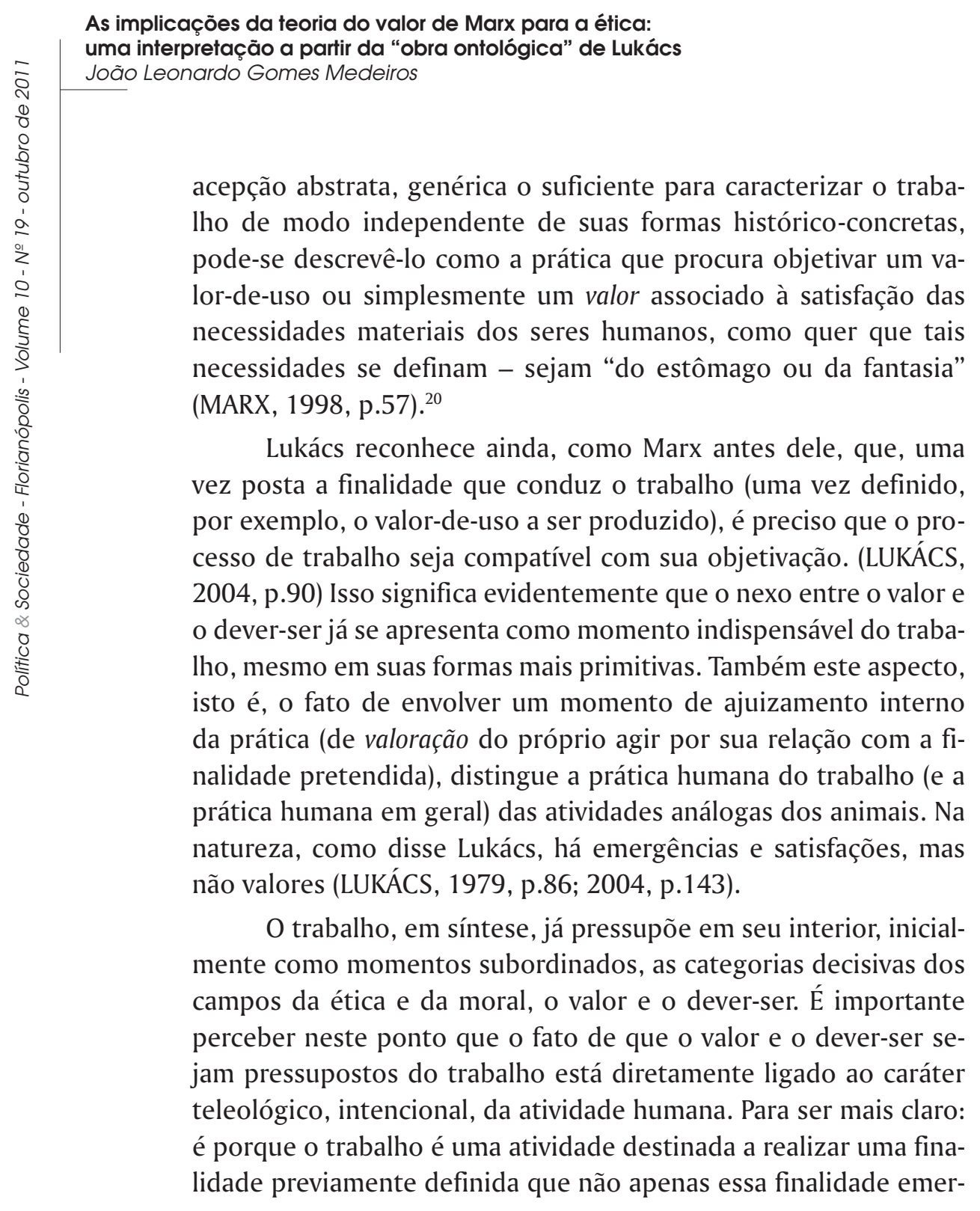

20 Valor-de-uso é, antes de tudo, valor, no sentido de finalidade, propósito, carecimento humano, e não no sentido de tempo de trabalho socialmente necessário, que é determinação específica da produção capitalista. É interessante perceber que Lukács nitidamente buscava uma forma de diferenciar o valor compreendido como tempo de trabalho socialmente necessário (específico) e valor como categoria geral, abstrata. $\mathrm{O}$ autor finda por optar por atribuir a expressão "valor econômico" para tratar do valor da economia em sentido geral, seja ele simplesmente o valor-de-uso ou a dupla valor-de-uso/valor (que muitas vezes Lukács descuidadamente chama de valor-de-troca). 
ge como guia diretriz de todo o processo de objetivação (ética), mas como a base do comportamento de quem trabalha (moral) e como critério para julgar a adequação da prática (juízo de valor). Nos termos de Lukács: "toda práxis, mesmo a mais imediata e a mais cotidiana, contém em si essa referência ao ato de julgar, à consciência etc., visto que é sempre um ato teleológico, no qual a posição da finalidade precede, objetiva e cronologicamente, a realização" (LUKÁCS, 1979, p.52).

É verdade que esse reconhecimento do valor, do dever-ser e dos juízos de valor como momentos do trabalho não é suficiente para caracterizar uma ética ou moral no trabalho e muito menos do trabalho. De fato, não é esse o propósito de Lukács. É, entretanto, crucial para o conjunto do argumento do autor a demonstração de que as categorias fundamentais da ética, do comportamento moral, já figuram como pressupostos da forma ontologicamente originária de prática humana, pois com isso se ilumina não apenas o nexo entre valor (ética) e práxis, mas a própria gênese do comportamento moral. Ademais, o caráter objetivo do valor (e, por seu intermédio, do dever-ser e dos juízos de valor) também pode ser demonstrado a partir do exame da práxis. Para isso, é necessário introduzir uma categoria fundamental na análise lukácsiana da práxis humana, a alternativa.

A atividade do trabalho, e a prática humana em geral, além de ser caracterizada como realização de uma finalidade pré-concebida, deve ser compreendida como escolha entre alternativas concretamente existentes. Em todo ato humano, não apenas uma finalidade (valor), mas um curso de ação (dever-ser) e todos os outros meios necessários a realizá-la objetivamente num mundo em si insensível com relação aos desígnios humanos (no caso do trabalho, objetos e meios de trabalho) são escolhidos, e outros negados (LUKÁCS, 2004, p.88-89).

Deixando de lado todas as questões (fundamentais no conjunto do argumento, mas dispensáveis para os propósitos deste artigo) relacionadas à formação da subjetividade necessária para desenvolver essa prática que elege alternativas, podemos perceber 


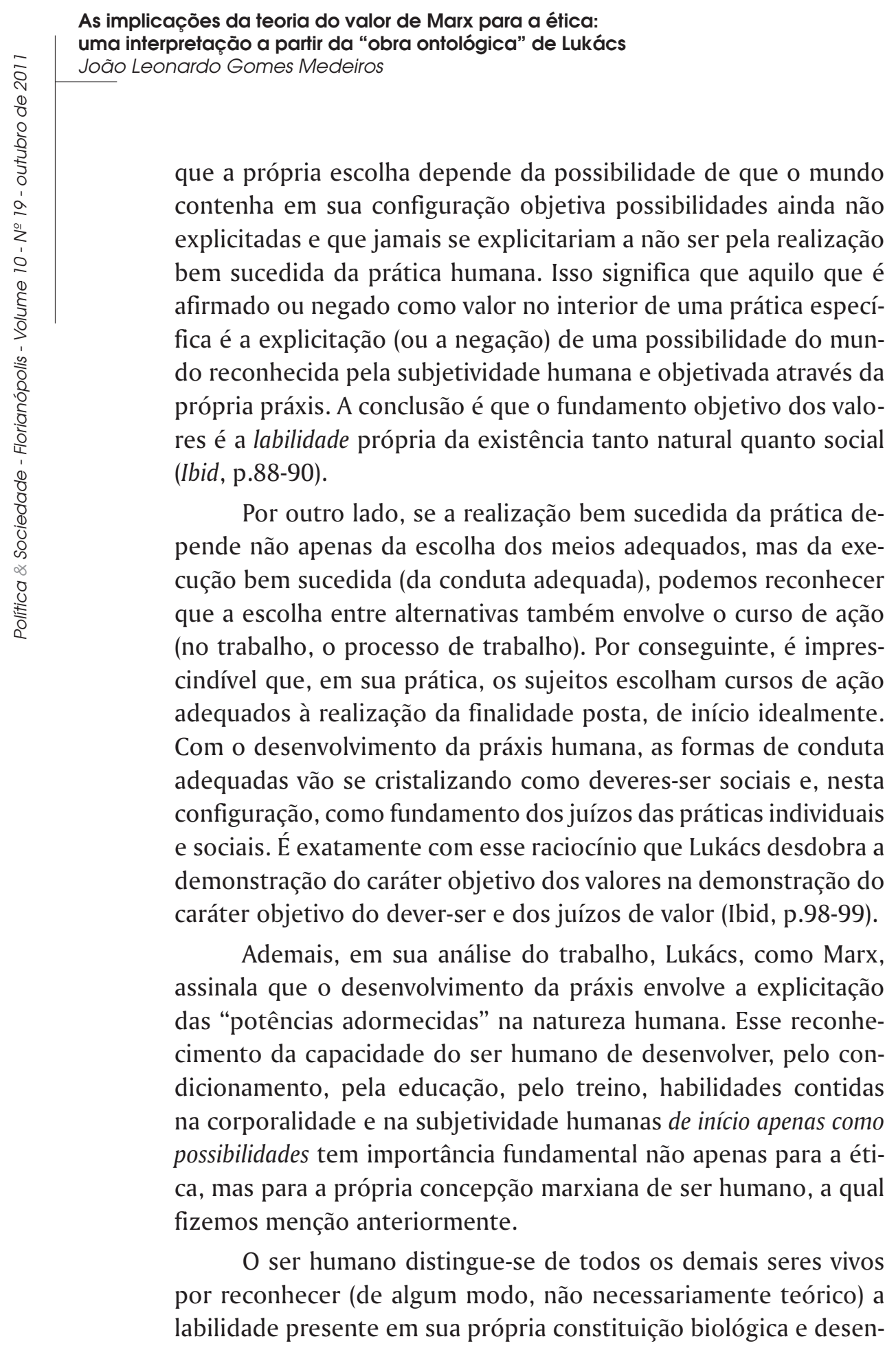


volvê-la pela prática, pelo agir teleológico. O momento originário desse desenvolvimento, observa Lukács, é precisamente o trabalho e é por isso que a análise desta modalidade de práxis se revela tão fecunda para o entendimento da especificidade do ser social (LUKÁCS, 1979, p.87).

Agora, não se pode nunca perder de vista o fato de que o trabalho seja tomado aqui "simplesmente" como modelo ontológico das diferentes modalidades de prática social. Como o trabalho, as práticas humanas são sempre atividades com condições materiais antecedentes, com condições causais, algumas das quais puramente "naturais" (a lei da gravidade, por exemplo), outras já transformadas pela atividade humana. O que faz o ser humano, em sua prática é, antes de tudo, reconhecer nessas condições materiais a possibilidade de dar origem a algo que delas não surgiria na ausência da própria prática: o resultado previamente projetado do agir, o valor que motiva e condiciona todo o processo de realização (no caso do trabalho, o produto). Ao transformar causalidades insensíveis às finalidades humanas em "causalidades postas" por sua prática, os seres humanos criam no mundo novas realidades. Ao assim fazê-lo, os seres humanos - além de mudar a própria natureza, como nos indicou Marx em sua análise do trabalho - abrem espaço para novas criações, para a posição de novas finalidades.

Em suma, em sua prática, os seres humanos ampliam as condições objetivas e subjetivas para o reconhecimento e a posição de novas finalidades, propósitos e carecimentos. Isso quer dizer, literalmente, que modificam o campo dos valores e, por seu intermédio, dos deveres-ser e dos juízos de valor. A cada estágio do desenvolvimento social, portanto, corresponde não apenas um conjunto de valores, uma ética, mas uma moral e uma forma de subjetividade (que talvez nós possamos chamar de ideologia). Para conhecer a ética e a moral de uma determinada época, enfim, deve-se descobrir os condicionantes da prática humana determinados pelo grau de desenvolvimento social. É a aplicação desse raciocínio à teoria do valor de Marx que nos permite, com base nas indicações de Lukács, desdobrá-la diretamente numa formu- 


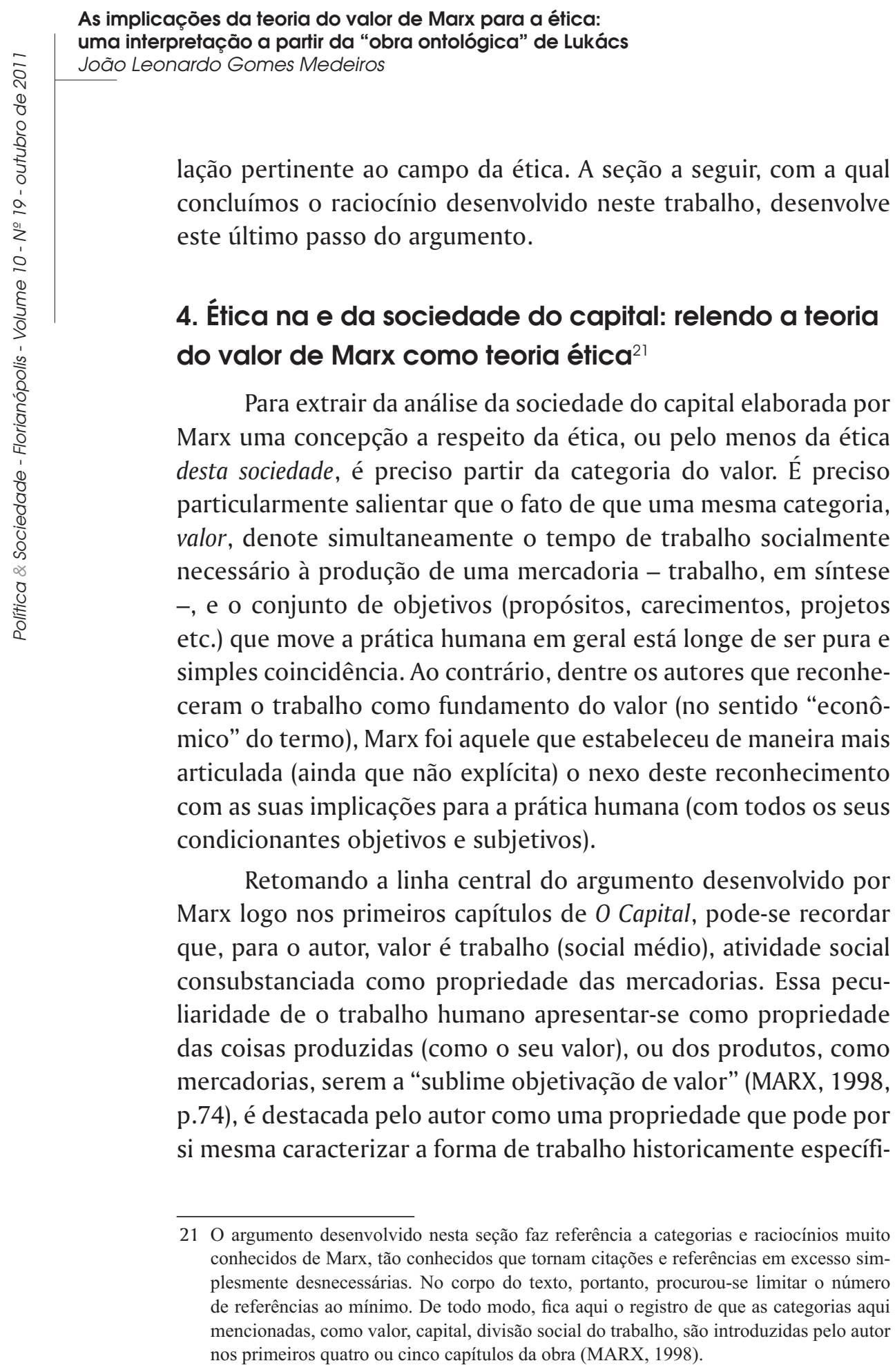


ca que corresponde à sociedade comandada pelo capital. Para demonstrá-lo, Marx examina os pressupostos históricos da emergência dessa forma misteriosa de objetivação do trabalho humano. ${ }^{22}$

Para que o trabalho possa figurar como propriedade das coisas produzidas, é preciso, em primeiro lugar, que os sujeitos necessitem comparar, por alguma medida comum a todos os produtos, as coisas que têm em posse. Para que essa comparação entre produtos possa ser efetivada com regularidade é preciso, por um lado, que os indivíduos sejam proprietários privados das coisas comparadas. É preciso, portanto, que a propriedade privada seja forma de propriedade dominante. Por outro lado, é preciso que as coisas sejam produzidas como objetos de satisfação de necessidades externas (o que torna socialmente legítimo o próprio ato de comparação regular entre posses pessoais). Ou seja, é preciso que a troca seja a forma de distribuição dos produtos dominante e, para isso, que a divisão social do trabalho seja complexa e os produtores especializados.

Se as coisas são produzidas para a troca e se a troca exige uma igualação entre coisas produzidas com base em alguma propriedade comum (ao menos) à maior parte do produto social, então é razoável considerar que o trabalho figure exatamente como medida desta comparação. Afinal de contas, as coisas trocadas são qualitativamente distintas e, deixando de lado o seu caráter qualitativo diverso, só resta a propriedade comum de serem produto do trabalho humano. Agora, sendo o próprio trabalho o fundamento

$22 \mathrm{O}$ argumento dos próximos parágrafos é uma síntese da síntese do raciocínio dos quatro primeiros capítulos do Capital apresentada em (DUAYER; MEDEIROS, 2008). Aquele texto, e agora a síntese dele, é inspirada na instigante releitura da obra proposta por Moishe Postone (1993) e na interpretação original de Mario Duayer (2010). Os leitores que conhecem com alguma profundidade a obra de Marx, certamente se ressentirão do fato de que o texto não traga para a discussão os trabalhos da juventude do autor - em particular, dos Manuscritos de 1844 e a Ideologia Alemã -, nos quais Marx desenvolve argumentos realmente fundamentais para o entendimento de qualquer ética que se pretenda marxista. A razão da arriscada escolha é uma única: o artigo tem como propósito central apontar implicações da teoria do valor de Marx para a ética e essa teoria ainda não havia sido desenvolvida nos trabalhos da juventude. É em O Capital que a teoria do valor de Marx recebe sua forma definitiva e, por isso, a obra é tomada como referência. 


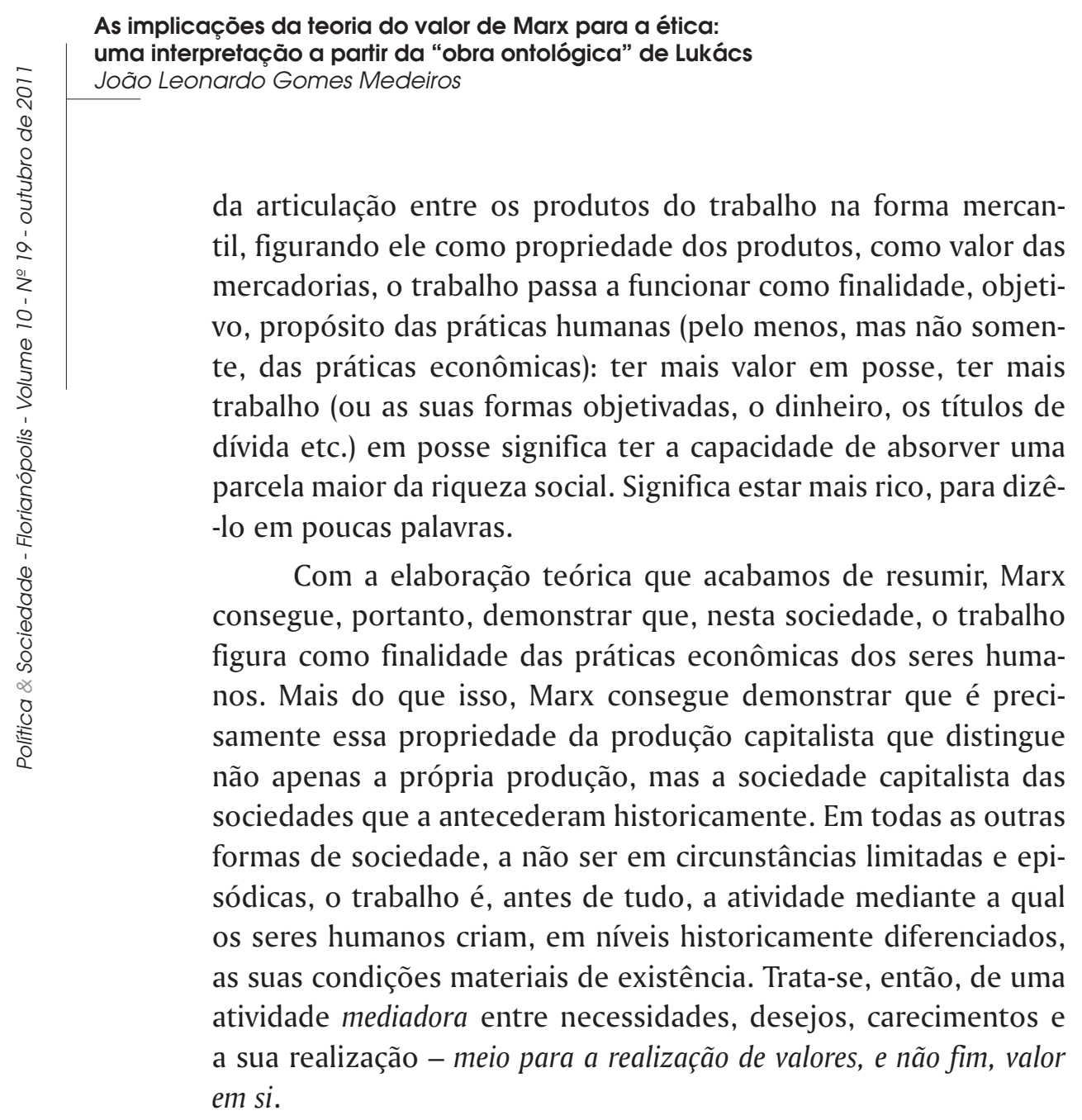

Naturalmente, o trabalho preserva, na sociedade capitalista, a condição de meio para a satisfação das necessidades humanas, mas assume prioritariamente a condição de fim, de valor. É esse o sentido da reinterpretação da teoria do valor de Marx que sugerimos a partir de Lukács: a teoria do valor de Marx nos revela que, em determinadas condições históricas, o trabalho, que é meio da satisfação de necessidades, emerge como valor. Aliás, o trabalho é $O$ Valor, no singular e sem qualificativos, deixando claro que se trata de uma finalidade humana que ele eleva por sobre todos os demais valores que movem a prática humana, subordinando-os. No capitalismo, para reforçar, o Valor (o Valor $=$ trabalho), subordina todos os outros propósitos humanos, subordina todos os outros valores, estéticos, afetivos, religiosos etc. e as formas de 
prática correspondentes, tornando a realização destes valores por essas práticas uma determinação secundária da existência humana. Secundária porque, dentre todas as finalidades que devem ser preenchidas pela prática de cada um dos sujeitos que vive nesta sociedade, a única efetivamente inescapável é a apropriação de riqueza sob a forma de Valor.

A categoria capital, tal como concebida por Marx, captura com precisão essa subordinação dos valores (ética) e das práticas humanas (moral) ao Valor. O autor nos apresenta o capital inicialmente como o valor que, em seu movimento, busca a valorização (isto é, a autoexpansão). Se, nesta mesma frase, trocamos a palavra valor por seu conteúdo efetivo, trabalho, chegamos a uma expressão da categoria capital que evidencia, em seus termos, a dinâmica autocentrada do trabalho na formação social capitalista: capital = valor que, em seu movimento, busca a expansão; ou seja, = trabalho que, em sua dinâmica, busca a expansão. É esse caráter autocentrado da dinâmica do trabalho - o fato de que o trabalho converta-se numa finalidade em si mesma - que caracteriza a forma de subordinação correspondente à sociedade capitalista. ${ }^{23} \mathrm{O}$ trabalho desta sociedade tem uma configuração estrutural, surgida espontaneamente das ruínas da sociedade feudal, da qual emana um movimento dinâmico no sentido da sua própria expansão.

Uma vez que essa dinâmica autocentrada do trabalho (o "sujeito automático" de que falava Marx ${ }^{24}$ - e tudo mais que ocorre na sociedade - é movida pela prática de indivíduos concretos, é preciso que todos os elementos que compõem essa prática estejam em conformidade com sua reprodução (a reprodução da dinâmica).

23 Diversos autores destacaram na leitura de Marx esse momento do argumento como o elemento central de sua análise crítica da sociedade burguesa. Dentre eles, podemos destacar: Kurz (1992), Postone (1993), Duayer e Medeiros (2008), Antunes (1999) e Mészáros (2002).

24 A tradução de $O$ Capital que empregamos neste trabalho evitou verter a expressão automatisches Subjekt, que consta no original, diretamente como sujeito automático. Optou-se, em meu juízo equivocadamente, por omitir a expressão e refrasear o texto da seguinte forma: "O valor passa continuamente de uma forma para outra, sem perder-se nesse movimento, transformando-se numa entidade que opera automaticamente". (MARX, 1998, p.184) 


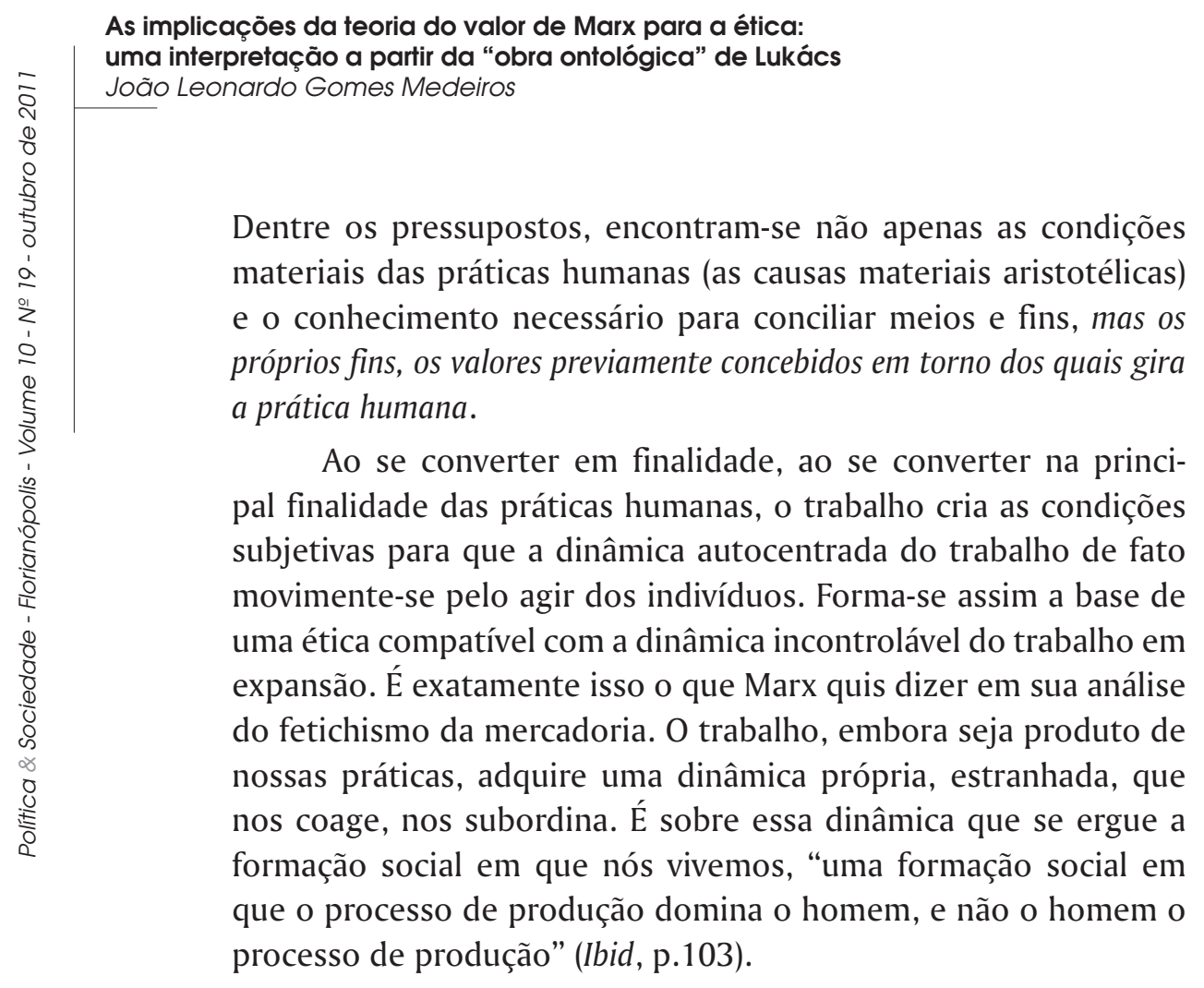

\section{Conclusão}

A título de conclusão, é interessante perceber como o exame das categorias centrais da ética, interpretadas à luz dos argumentos de Lukács, de fato pode servir para extrair da obra de Marx uma interpretação dos determinantes morais de nossa época que parece ser congruente com o sentido geral da crítica do autor. Para abreviar a exposição, pode-se partir da seguinte implicação do argumento da última seção: se tal argumento estiver correto, para Marx, a sociedade do capital é, na verdade, a sociedade do trabalho, a sociedade do trabalho estranhado, a sociedade da ética do trabalho estranhado.

Como em toda ética, a ética do capital desdobra-se numa moral, num conjunto de deveres-ser. Como sempre, o dever-ser correspondente depende da condição particular em que se encontram os indivíduos concretamente existentes. No caso da sociedade capitalista, a condição de classe, por ser determinante direto da condição econômica particular dos indivíduos, torna-se o elemento fundamental na determinação do dever-ser correspondente 
à realização do Valor. Para a classe trabalhadora, a realização do Valor exige o comportamento adequado ao aproveitamento pelo capital (ou seja, o enfrentamento da concorrência entre os trabalhadores). Para a classe capitalista, exige-se o comportamento adequado para a expansão do capital (concorrência entre capitais). ${ }^{25}$

Do ponto de vista da ética, é preciso enfatizar que os valores dos sujeitos das duas classes são subordinados ao capital (ao Valor), embora as condições de subordinação sejam distintas e, no geral, obviamente mais favoráveis para a classe dominante, a classe capitalista. Sejam quais forem as condições de subordinação, entretanto, o fato é que trabalhadores, ocupados ou não, capitalistas, rentistas, ricos e pobres, a ninguém, nesta forma de sociedade, é dado o direito ou a liberdade de se opor ao movimento dinâmico do capital, sob a pena da perda da condição social e, no limite, física. Para Marx, livrar-se dessa subordinação exige livrar-se do capital. Ou seja, livrar-se do Valor, do trabalho objetivado como valor.

É importante ter em conta, por fim, que, se o Valor é a base da ética do capital, a ética do trabalho que subordina o comportamento dos sujeitos (todos os valores, de todos os sujeitos) na sociedade em que vivemos, então o caráter objetivo da ética não apenas se explicitou em nosso tempo como adquiriu uma forma material - a forma social do valor, o dinheiro. Pode-se sugerir que essa peculiaridade de nossa época cria o contexto favorável para argumentar que os fundamentos da moral não se encontram exatamente na consciência dos sujeitos, como pretendem as diversas teorias idealistas, mas sim nas próprias relações sociais. Se, pela razão aludida por Eagleton na passagem citada no começo do texto (ou por qualquer outro motivo), Marx não se valeu do contexto e revelou as implicações de sua crítica social para o campo da ética, talvez seja mais do que a hora de fazê-lo.

Recebido em: 21.09.2010

Aprovado em: 30.06.2011

25 No interior de cada classe, condições particulares de ocupação, de qualificação, condições físicas e mesmo genéticas dão contorno final ao tipo de comportamento adequado (útil, eficiente, bom etc.) ao aproveitamento pelo sujeito automático. 
As implicações da teoria do valor de Marx para a ética: uma interpretação a partir da "obra ontológica" de Lukács João Leonardo Gomes Medeiros

\section{Referências}

ANTUNES, R. Os Sentidos do Trabalho: ensaio sobre a afirmação e a negação do trabalho. São Paulo: Boitempo Editorial, 1999.

ARISTÓTELES. Ética a Nicômaco. Bauru: Edipro, 2007.

BHASKAR, R. Scientific Realism and Human Emancipation. New York: Routledge, 2009.

. The Possibility of Naturalism. Brighton: Harvest, 1998.

A realist theory of science. London: Verso, 1997.

BRENKERT, G. Marx's ethic of freedom. Boston: Routledge, 1983.

DUAYER, M. Mercadoria e Trabalho Alienado: Marx e a crítica do trabalho no capitalismo. Artigo apresentado no IV Coloquio Internacional Teoría Crítica y Marxismo Occidental: "El pensamiento tardío de György Lukács”. Buenos Aires, 2010. $\overline{\mathrm{n} .35,2001 .}$

Marx, Verdade e Discurso. Perspectiva, Florianópolis,

DUAYER, M.; MEDEIROS, J. L. Marx, Estranhamento e Emancipação: o caráter subordinado da categoria da exploração na análise marxiana da sociedade do capital. Revista de Economia, Curitiba, v. 34, p.151-161, 2008.

.Under-labouring" for ethics: Lukács's critical ontology. In: LAWSON, C. et. al. (org.) Contributions to social ontology. Oxon: Routledge, 2007.

DUAYER, M.; MEDEIROS, J. L.; PAINCEIRA, J. P. Desventuras Filosóficas da Ciência Econômica (naturalização da sociedade do capital e relativismo ontológico). Artigo apresentado no V Encontro da Sociedade Brasileira de Economia Política, Fortaleza, 2000.

EAGLETON, T. Depois da Teoria. Um olhar sobre os Estudos Culturais e o pós-modernismo. Rio de Janeiro: Civilização Brasileira, 2005.

JAMES, W. J. Pragmatism: A New Name for Some Old Ways of Thinking. New York: Longman Green and Co., 1907. 
KAIN, P. J. Marx and Ethics. Oxford (US): Clarendon Press, 1991.

KURZ, R. O Colapso da Modernização: da derrocada do socialismo de caserna à crise da economia mundial. Rio de Janeiro: Paz e Terra, 1992.

LESSA, S. O Mundo dos Homens: trabalho e ser social. São Paulo: Boitempo Editorial, 2002.

LUKÁCS, G. As Tarefas da Filosofia Marxista na Nova Democracia. In: LUKÁCS, G. O Jovem Marx e Outros Escritos de Filosofia. Rio de Janeiro: Editora da UFRJ, 2007a.

As Bases Ontológicas do Pensamento e da Atividade. In:

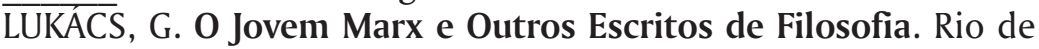
Janeiro: Editora da UFRJ, 2007b.

Ontología del Ser Social - El Trabajo. Buenos Aires: Herramienta, 2004.

História e consciência de classe: estudos sobre a dialética marxista. São Paulo: Martins Fontes, 2003.

Ontologia do ser social - Os princípios ontológicos fundamentais de Marx. São Paulo: LECH, 1979.

MARX, K. O Capital: crítica da economia política. Rio de Janeiro: Civilização Brasileira, 1998.

- Para a Crítica da Economia Política. In: MARX, K. Manuscritos Econômico Filosóficos e Outros Textos Escolhidos. São Paulo: Abril Cultural, 1974.

MEDEIROS, J. L. The values of the world against the "world" of values: practical contradictions of economic theories of "welfare". Journal of Critical Realism, 4(I), Leiden, 2005.

MÉSZÁROS, I. Para Além do Capital: Rumo a uma Teoria da Transição. São Paulo: Boitempo Editorial; Campinas: Editora da Unicamp, 2002.

POSTONE, M. Time, Labor, and Social Domination: a Reinterpretation of Marx's Critical Theory. Cambridge: Cambridge University Press, 1993. 


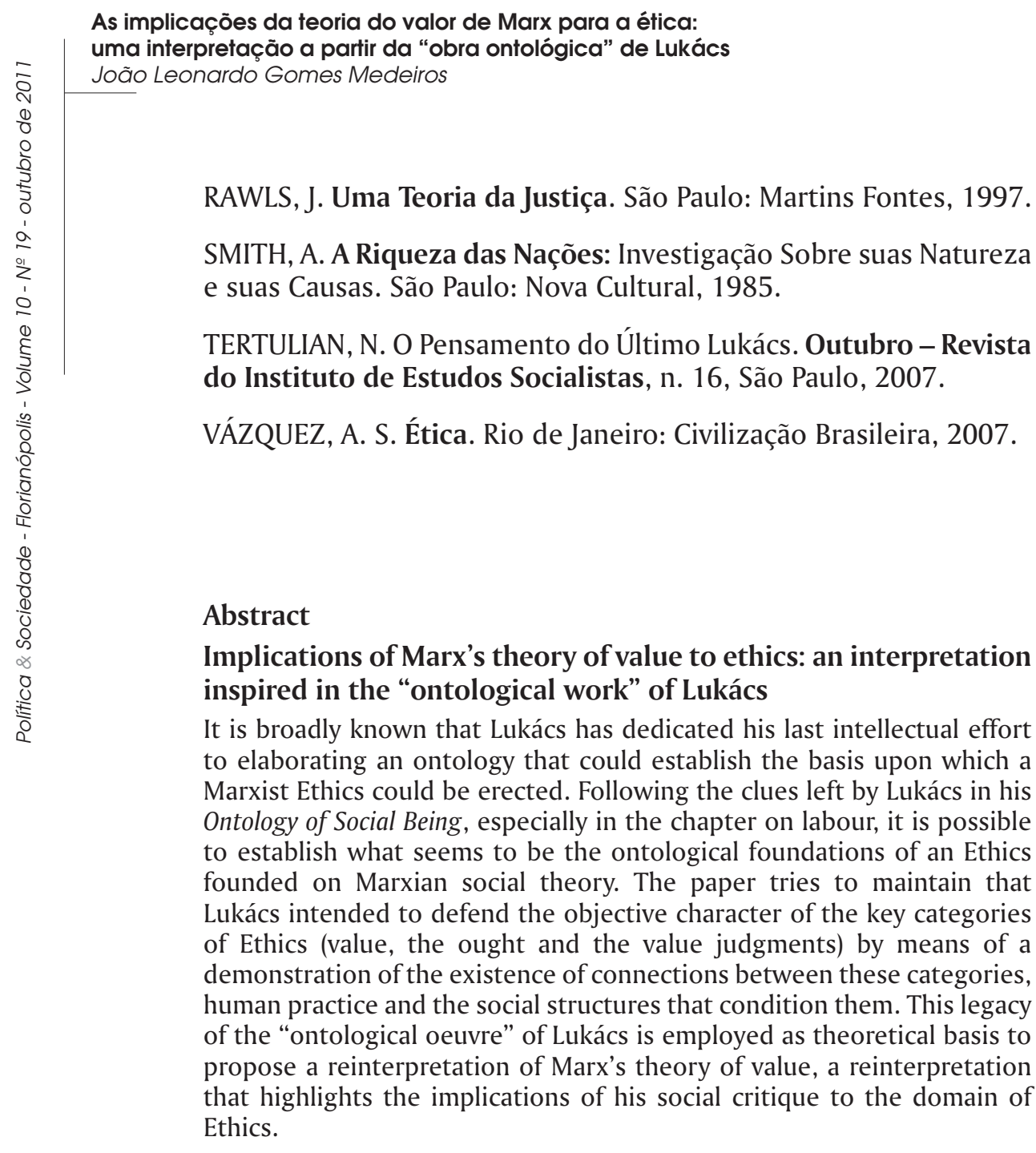

Keywords: theory of value, Marx, Lukács, ontology, ethics, human practice. 